\title{
The Master as a Historical, Cultural and Pedagogical Category: An Introduction
}

\begin{abstract}
The Master is a semantic category which exists in every culture and in every historical moment in the world. The tasks and the role of the master in society are changing, but nevertheless, masters continue to support the development of science, art, education or moral systems. There are many different contexts for this category that reveal specific aspects of being the master, as well as the value of the relation between a master and a student. The aim of this text is to characterize them and take readers on a literary and scientific journey through different cultures, past centuries, and social institutions that will help us to better understand the phenomenon of the master(s).
\end{abstract}

Keywords: master, master-disciple relationship, semantic categories, cultural context.

\section{Mistrz jako kategoria historyczna, kulturowa i pedagogiczna. Wprowadzenie w problematykę}

\begin{abstract}
Abstrakt
Mistrz jako pewna kategoria semantyczna istnieje we wszystkich kulturach i w każdym momencie dziejowym świata. Jego zadania i rola w społeczeństwie zmieniają się, lecz mimo to mistrzowie trwają i wspierają rozwój nauki, sztuki, edukacji czy też systemów moralnych. Powoduje to, że pojawiają się liczne konteksty, które odkrywają konkretne aspekty i cechy mistrzostwa, relacji „mistrz - uczeń”, a także pojęć pokrewnych np. szkół naukowych czy autorytetu w nauce. Niniejszy tekst ma je unaocznić i zabrać czytelników na literacko-naukową wycieczkę po kulturach, wiekach, instytucjach, które pozwalają lepiej zrozumieć, na czym polega fenomen mistrzostwa czy relacji mistrz - uczeń.
\end{abstract}

Słowa kluczowe: mistrz, relacja mistrz - uczeń, kategorie semantyczne, kontekst kulturowy.

\footnotetext{
* Nicolaus Copernicus University in Torun, Department of Social Pedagogy and Social Work.
} 


\section{Introductory remarks}

The story of mastery must begin with a rather obvious reflection - the master as a specific figure, a term, a notion and a semantic category, exists in almost every culture and historical moment in the world. ${ }^{1}$ Their tasks as well as their role in societies are subject to change, but, regardless of those changes, masters continue to exist and support the development of science, art, education or ethic/moral systems. There are many contexts that demonstrate particular aspects and features of mastery, the "master-disciple" relationship, as well as some related concepts such as e.g. "academic schools" (Goćkowski, Siemianowski 1981), and authority in the academy (Rybicki, Goćkowski 1980; Znaniecki 1984). The aim of this article is to present these different contexts and invite readers on a literary and scientific journey through cultures, centuries and social institutions which will help us to better understand the phenomenon of mastery and the relation between a master and a disciple.

Some of the proposed paths may seem surprising, or not to provide direct answers. The aim to this article is to:

1) present chosen, semantically rich traditions in thinking about the master and the disciple which have appeared in different societies and cultures;

2) point to important qualities of the master by confronting the concept with the figure of a teacher;

3) mention other, less conventional ways of thinking about the master and the student, which are connected with various-complex and not always correctly assessed-phenomena in contemporary culture.

It is necessary to begin with several introductory remarks that will provide a frame for the presented argument. Firstly, the final choice remains the author's decision - as it is always in similar cases. The possibility of finding other examples does not invalidate, nor does it weaken the argument-it simply makes it different. What follows is in no way a "mandatory," academic lecture that will present a systematic overview of "mastery," as this subject matter has been already discussed in many critical works-referred to in the article-and the length of this paper excludes this possibility.

Secondly, although the choice remains the author's decision, it is not random but teleological. It is supposed to lead to an observation about the many, today often forgotten, aspects in the master-disciple relationship, even in those traditions which seem obvious for "mastery" (e.g. a guild system or a guru). The examples are thus chosen according to what they can offer us today when we analyze, interpret

\footnotetext{
${ }^{1}$ I am aware of the fact that such a statement may seem like a generalization which will be untrue in certain, unique and individual cases. This does not change the fact that the presence of "a master" can be considered as a sort of common trait shared by many cultures, even if both this category and this way of understanding the world has been the subject of criticism. Additionally, the possibility of practicing different types of "mastery" does not negate the existence of features that are common for this category.
} 
and update the category of "mastery." In this sense it is a narrative about different models that are temporarily and spatially distant from each other, one that will focus on the forgotten aspects of mastery.

Thirdly, this explains the decision not to describe in detail any of the models, but instead to emphasize the various aspects that are omitted or not sufficiently emphasized, especially today. The aim is not to present a full reconstruction-as has been done many times in a historical or cultural studies paradigm-but to pragmatically use these contexts of mastery to create the possibility of engaging in such relationships today, especially in both traditional and alternative pedagogy.

Fourthly, the examples are not presented for the sake of comparison, or some cultural comparative studies. Nevertheless we can use the advice formulated by Haun Saussy, one of the most important modern comparatists, who states that:

Comparative literature is engaged with specificity and relation: the specificity of the object whereby it exceeds established models of discourse, and the relations that a new reading creates among its objects. Every comparative project is in some measure an experiment, and the most imaginative ones best answer the peremptory challenge: Why should we be interested in this encounter? What can you show us that we could not have learned for ourselves by taking each object in the traditional perspective of its discipline? (Saussy 2006: 24)

A comparative study is teleological, and also-it is supposed to be persuasive, and the key to comparison lies in the hands of the comparatist. From this perspective the search for historical and cultural contexts of mastery that are still significant today can lead us to many different and remote traditions.

And finally, the aim of this article is not to idealize a master (through the use of simplified models referred to in the text), but to build ideal types-in the meaning proposed by Max Weber (2011) - abstract and distanced from both individual and historical-cultural manifestations. They will in turn provide insight into the various aspects of mastery that are important today. Naturally, this strategy can be accused of ahistoricism, or of being an attempt to create a universal mother. However, that is not the case. I only wish to broaden the horizon of expectations-this time referring to the category introduced by Edmund Husserl $(1975,1982)$.

Therefore, the structure of the argument will be the following: first I will present chosen conceptualizations of the master-disciple relations, as well as mastery in general. This will enable me to provide a common frame, consisting of categories that are used to think about different figures of masters. Next, I will reveal different aspects of mastery by providing historically and geographically differentiated examples. Finally, selected aspects and advantages of selected models of mastery will be applied to the contemporary situation and the discourse of pedagogy. These educational contexts will serve as potential recommendations as to how we can rethink mastery today. 
It is necessary to begin with the following question: who is a master? Is it someone who we learn from, to gain knowledge and abilities? Is the transmission of knowledge crucial in the master-disciple relationship? Is the master aware of his tasks and responsibilities? Does he want to be a master and an authority figure for others? Is he self-conscious in how he shapes his role, position and biography as a master? This issue of "NOWIS" is dedicated to answering these and other questions. For the purpose of this article it is only a theoretical frame for the introduction to my argument. Władysław Stróżewski and Lech Witkowski (as well as, indirectly, Mircea Eliade) will serve the role of guides.

In his essay entitled Promieniowanie mistrza, Stróżewski characterizes the relationship with a master, and helps us to recognize it: "When faced with true greatness, we are never intimidated and we never feel humiliation, but rather we are lifted up as though something important and great has been growing inside of us" (2007). It is a surprising and rarely raised observation, since it does not focus on the attributes of either side of the relationship, but on its character. It connects the master, who for Stróżewski is primarily an authority figure, a decisive instance possessing knowledge and competences needed not only for creating a work of art, but for transmitting skills-with a disciple, who in this relationship is considered as an equal to the master.

The master possesses absolute authority in every domain, including the moral or ethical domain, although we must differentiate professional authority figures from moral authority figures. Nevertheless, in order to deserve the title of an authority figure, one requires mastery, perfection in some domain e.g. in literature, art or science, but also in blacksmithery. A master's moral perfection is connected with a sense of responsibility for his words and actions, as well as being the result of what he has or has not done for his students (this also includes the imperative of speaking the truth and acting on it). This is accompanied by openness, tolerance, a positive approach to a disciple and his work-not requiring simply coping the master's greatness-and respect for the disciple's individualism. This is how a master shows his greatness, his ability to perceive the specific character and talent of the pupil and to allow him to grow according to a distinct, individual model. This feature of the master is emphasized also by Lech Witkowski in one of the most important essays about masters entitled Mistrz jako obosieczna zasada komunikacji (dylematy pedagogiczne) published in the book Między pedagogika, filozofia i kulturq. Studia, eseje, szkice (2007). Mastery carries a destructive potential since it poses a threat both for the disciple, who cannot spread his wings under the control of a master-tyrant and autocrat, and for the master, who may himself stop evolving and learning, and no longer be open to anything new, instead requiring only a duplication of what he had already discovered. Witkowski writes that: 
(...) if what Mircea Eliade says is true, that every important existential experience can be characterized as an initiation, then it is even more crucial to notice that in the sphere of culture it is... the master who has become an essential, but difficult or even hazardous medium of initiation. The threat is due to the presence of the master (in his different expressions and variants), but at the same time also to his absence in the adept's trials and rooting in the world. The master does not have to be old or even alive; it is enough for his thinking and experience to be life-giving (Witkowski 2007: 267).

Stróżewski formulates one more condition: the master does not have to be and should not be a guru (in the colloquial sense of the word), or as we would say today-an idol. He does not follow the disciple in every task and does not show him what to do or what not to do. He is supposed to build a relationship the aim of which is liberation, and also-as Witkowski repeats later-he must serve the role of guide through the initiation. If we follow Witkowski's argument, we can say that being over-dependent on the master and copying his biography may end up squashing the disciple's initiative, original thinking and openness to intellectual and spiritual evolution. It is a trap that is difficult to escape from without hurting the relationship itself, the master's authority or the well-being and self-assessment of the disciple.

The master is characterized by greatness, and it is this quality in different cultures that has for many centuries helped to counter immaturity with maturity, a beginner's enthusiasm with experience, youth with old age, a thirst for knowledge with knowledge itself.

\section{The confusing paths of mastery}

These statements may seem typical in the context of our shared common cultural knowledge. However, if we wish to dig deeper into the characteristics of the master as a figure or analytical category, we must move to interpretations of the masterdisciple relation which are unconventional, rare, or forgotten. The same applies even in cases when the history connected with particular examples is well-known. What often eludes us is the hidden master-disciple relation and its particular character. Among these forgotten relationships we can find the craft guild with a hierarchical order of dependence between the master and the disciple; the Platonic Academy, existing in ancient Athens; Zen Buddhism as a philosophical system originating from the enlightened Master-Buddha; as well as the phenomenon of the guru, a teacher and priest in Hinduism.

We will discuss specific narratives about people and phenomena, which not only provide us with new insight, but also point to the attributes that characterize various master-disciple relationships, the master's features, and finally the process 
of becoming a master. This will allow us to think about the master (and the disciple) from a different perspective to the one dictated by common sense. What follows are model stories.

\section{Education in a stranger's home}

The stories about masters are intentionally not presented chronologically. We are used to perceiving the history of education from the perspective of European culture, which according to many historians originates in ancient Greece and Rome. It is valuable to broaden this perspective, to move things around, and begin with a tradition of indirect education, that is: education in a stranger's home. This tradition was the subject of Józef Chałasiński's doctoral dissertation written in 1928 under the supervision of another Polish sociologist-Florian Znaniecki (1928, 1930). Today, it is helpful to return to his theory. I am inspired to do so by one of my own Masters-Ryszard Maciej Łukaszewicz, a professor of pedagogy and a practitioner, creator of the Wrocław School of the Future. ${ }^{2}$ In his Wychowanie $w$ domu obcym jako instytucja społeczna: studjum $z$ socjologii wychowania (Chałasiński 1928³), Chałasiński, basing his argument primarily on historical literature, presented an analysis of the important social institution of upbringing.

This process is necessary, because:

The content of upbringing is the transmission of social heritage that is responsible for developing certain tendencies and attitudes in an individual, certain ways of thinking and feeling; it imbues them with ways of testing actions, necessary for upholding homogeneity and continuance, and sometimes development of a group (ibidem: 16).

It is therefore a process which is responsible for group continuity in a social sense, as is reproduction in the biological sense. Chałasiński quotes the words of Paul Barth, a German philosopher and pedagogue, professor at the University of Leipzig at the turn of the $19^{\text {th }}$ and $20^{\text {th }}$ centuries, who wrote that: "Upbringing means a constant transplanting of society" (ibidem).

Chałasiński argues that social orders are based on irrational factors, since there is no objective truth behind the existence of institutions, including the institution of a master or teacher. However, institutions are based on different belief systems, and their moral authority stems primarily from their long existence. The older an institution, the more difficult it is to study the belief system it is

\footnotetext{
${ }^{2}$ http://www.wsp.wroc.pl/ [accessed: 20.09.2018].

${ }^{3}$ The following argument is based on Chałasiński's reflections, and I give specific reference points only when I am reconstructing his views or quoting his text. However, following my introductory remarks, the aim of his article is different, therefore I remain within the scope of Chałasiński's considerations, especially in regards to his proposed normative findings. Indeed, his work played a crucial role in the pedagogical discourse, and because of that is well aligned with my own narrative strategy as well as the aims of this article.
} 
founded on. The same can be said about the process of bringing up someone young, the main premise and constitutive feature of which is the fact that a person is educated first and foremost through social contact with others and through communication. It is the sine qua non condition for an individual's co-existence with and within a given group.

As Chałasiński writes: "The co-existence of adolescents and adult members of a group is enough to educate them, regardless of whether the elders consciously choose to educate the young" (ibidem: 26). He calls this educational process spontaneous and non-reflective because it is not controlled in any special way. However, it is up to society to decide which educational sphere is left to this type of upbringing:

There is a tendency in modern societies to rationally regulate the entire life through the act of isolating the world of children and adolescents from the world of adult members of the group. Complete isolation is never possible to achieve and spontaneous upbringing will always play an important role (ibidem: 27).

The situation is different in so-called primitive societies, since their rational educational sphere is limited and has no educational organization. The family is responsible for the transmission of knowledge, which in itself organizes the division of work and responsibilities among the family and the entire community. However, because of the complexity of the social organization, spontaneous and non-reflexive upbringing becomes insufficient. On the one hand, there is a need for a selection of the knowledge that is transmitted to adolescents as a tool in their hands, and one that serves to uphold and cultivate the group, and on the other hand, there is a need to section off a system of activities and educational organizations, which results in the creation of specialized social institutions.

There is a particular, indirect form of educating that was not recognized by Chałasiński at the time he was writing his book-that is, upbringing in a stranger's home. It is situated between the primitive, non-reflexive and the modern, specialized upbringing. This type of education had appeared in different types of organizations-in the sphere of knighthood and in craft guilds (although in the context of the Middle Ages we may also add to the list the priesthood, especially with its idea of monastic education, the category of a novitiate, the process of moving up the hierarchal ladder, the different rites of passage etc.).

The idea of a craft guild originates alongside the emergence of cities and their typical institutions. The members of the guild are not concentrated around any master craftsman, but are subject to guild laws which Chałasiński calls "a knowledge of impersonal nature" (1928: 118). The guild is a professional group with a hierarchical structure and elected authorities. It is a highly hierarchical and codified institution. A charter would describe every aspect of guild life-from the 
issue of how an apprentice chooses a master, through the available forms of education, up to the issue of providing alimentation for the students. There was no room for discretion, so the apprentice could call upon the guild court whenever he felt that the laws were not respected. Guilds were small institutions, since there was a strong tendency to limit the number of guild members. Sometimes it was even a closed number, which corresponded with the social demand for products and services in a given field. The reasons for this were primarily economical, however, it also affected the creation of strong interpersonal relations which made the guild an especially closely-knit community characterized by powerfully emotional social ties.

A guild is primarily characterized by a psychological collectivism, which means that there is no individual thinking among its members, as was typical for Plato's Academy, which I shall discuss in a moment. Although it was not a commune, each member of a guild would think about himself only through the category of "us." On the other hand, a guild had a tendency to isolate itself and close its ranks from the outside world. Belonging to a guild gave a craftsman social recognition. A guild's morality was based on the notion of "us" and "them," and exclusion from the brotherhood was not unlike a curse. Such a person would automatically be recognized as someone from the outside, a stranger who was prohibited from learning the guild's secrets.

Educational problems were also the subject of guild charters. At first, the guild had no control over the educational process, nor the educating community (a workshop, a family), and education was spontaneous and non-reflexive. The need to write down regulations regarding the educational process appeared only when collectivism began to be slowly replaced by individualism. The entire guild was responsible for education. The presence of apprentices in the master's house was necessary for the group to continue to exist. However, a person could only practice a craft after receiving the guild's approval. Only the master had the right to practice his craft individually, and the title was given by the guild after years of learning. What is more, taking on an apprentice was not a decision made by the master but by the entire guild. An apprentice was entered into a student register and from that moment remained under the protection of the guild and its mandate - the master. It was often the guild which chose a master for an apprentice.

The cooperation between a master and an apprentice began with a "joining," an agreement or contract that was secured in front of a group of sworn men. The master had to be a man wealthy enough to provide for the student, and also honest and righteous. He had to provide the apprentice with full-day provision, accommodation and food, while also spending time on teaching the craft. The apprentice reciprocated this with his loyal service and hard work. If things turned out differently, the student had the right to terminate the contract. All in all, it was a burden and something that demanded responsibility, so often a master could 
obtain an apprentice only after several years of work. The number of students was limited because of the difficulties and responsibilities connected with the craft. Termination of the contract was also strictly regulated, and you were not allowed e.g. to sell your apprentices to other master craftsmen. It is important to remember that a master was primarily a representative of the guild, its mandate, and was therefore subject to the group's control. Keeping apprentices and educating them was his duty. Older students held the same responsibility, as they had to take care of the younger apprentices.

The master-apprentice relationship was only a temporary stage for both subjects. For the master-it was to educate the apprentice for the guild, and thus strengthen that guild's cadre as well as its position in the city, while also benefitting from several years of the apprentice's free labor; while for the apprentice-it was to gain the skills of a craftsman, take the first steps on the road to independence: becoming a journeyman. Then, although he still remained under the control of his master, an apprentice-journeyman had access to many more freedoms and rights, for example, he could now take part in the life of the guild and receive payment for his work. This stage lasted for a couple of years, until the craft exam.

Chałasiński writes that the master-apprentice relationship is an example of a specific personal and educational relation. The most important part of it was its formal and economical character. When deciding to begin their cooperation, both sides signed a binding contract the termination of which resulted in sanctions. Its realization was monitored by the entire guild. The characterized model does not leave much space for individualism or "intellectual fascination," which is often considered as a significant feature of the master-disciple relationship. Here there is a contract, law, finances and collective decision-making that is based on the good of the entire community. These are some of the elements which we tend to forget about when we think about masters today.

\section{Platonic Academy}

Another example of mastery is the school founded by one of the most brilliant Greek philosophers-Plato, ${ }^{4}$ who became an inspiration for many generations of teachers and sages. It is important to remember that in Ancient Greece there were two completely separate models of education (Kot 1996). The goal of Spartan education was to shape loyal and well-trained soldiers who in the future would protect their homeland. It was therefore an education oriented towards the state,

\footnotetext{
${ }^{4}$ A short recapitulation of Plato's life, as well as a long discussions of his views, may be found in the second volume of Giovanni Reale's History of Ancient Philosophy (2001). A separate issue which demands a more detailed reflection in the context of master-disciple relations is the issue of orality and literacy, with both frequently appearing in the discussed examples. It has an impact on such issues as the transfer of knowledge, educating, contract and - as research on Plato and the Ancient Greeks shows us - also on the way we think (see Reale 2001: 27-71). For a detailed discussion of these issues see Eric A. Havelock (2007).
} 
which left no room for individualism but instead valued loyalty and obedience. Athens, on the contrary, and because of its cosmopolitan and more liberal character, followed a different ideal of education. This model imagined a citizen as comprehensively educated, combining harmonious physical shape and strength with mental, moral and aesthetic development (I avoid mentioning its practical application as well as any deviation from the ideal, as I am more interested in the projected patterns of behavior and ideal types). Children gained knowledge from their teachers and adolescents were taught in gymnasiums, institutions which focused both on intellectual as well as physical development. Philosophers would often visit gymnasiums to engage in discussions with students. Was Plato also among them? We do not know. Nevertheless, we can be sure that it was because of him that the world (and most certainly social consciousness) discovered the idea of dialogue as a teaching method and a way of cultivating knowledge.

Today, we know that it was first the sophists, and later Socrates who introduced the concept of dialogue into education, but it was because of Plato's Dialogues that the idea and form of dialogue became a way of conducting philosophical disputes.

According to the information contained in Plato's writing, he met Socrates when he was twenty years old. He was his most loyal student for eight years. However, his teacher was sentenced to death for his controversial opinions and killed by poison (which Plato describes in Phaedo, 2002). After the death of his master Plato left Athens together with Socrates' other disciples and traveled around Greece, Egypt and the Greek colonies for twelve years. He returned to Athens as an adult man, and founded a school of philosophy in a grove of olive trees where the grave of Akademos was located. It was supposed to provide education for remarkable individuals and future rulers, and so a lot of time was spent on disputes concerning the shape and order of the country. Plato wanted to teach his disciples how to continue studying on their own, to engage in philosophical inquiries and self-development.

The Platonic Academy offered education primarily in philosophy (dialectics) and politics, but also in other fields: mathematics, astronomy, natural sciences. Above the entrance to the Academy was inscribed the phrase: "Let None But Geometers Enter Here." This meant that in order to engage in discussion, a student had to be properly prepared, ready to take part in disputes-present arguments, experience intellectual failures, learn to control his emotions.

The Academy was not organized in the way the craft guild was, although it was governed by a head of the school who held the title of "scholarch." Plato became the first scholarch and would serve this function for forty years. As Władysław Tatarkiewicz writes, it was not so much a school as an intellectual parlor, "an institute of scientific cooperation" (1998: 102). It accepted both young and adult students and scholars who wished to engage in philosophical disputes. The school's achievements are impressive: 
The outstanding astronomer Eudoxus finished the Academy. We know that the school also taught about the classification of plants and animals, in relation to Plato's logical theory of the division of concepts. Indeed, even the most diverse academic works did not exhaust the Academy's curriculum; it was not only a scientific union but, following Plato's own aspirations, it was supposed to serve the idea of the Good (Tatarkiewicz 1998: 102-103).

In order to be accepted to the Academy, a candidate had to pass an exam conducted by Plato himself-it was therefore the master himself who would choose his associates and disciples. As the first scholarch, Plato set the way for the entire educational process-topics, forms, problems. Teachers at the Academy gave lectures, organized seminars, conversations and disputes (written texts were used as starting points for discussions), which often happened during walks around the garden or in city propylaea. Lectures were given either by Plato himself or one of his students.

Tatarkiewicz writes that "In legal terms, the school was included among religious associations, as it gave greater security guarantees for property and made it possible for the school to exist until the year 529 CE when Justinian closed it" (1998: 103). Despite the fact that the outside form of the school endured, its interior was unstable and prone to change-each successive scholarch would promote his own philosophical system. This points to two features of the Academy-its openness to new ideas and new personalities. Furthermore, it was subject to a process that was typical for the master-disciple relationship: a student was taught by a master, but after reaching puberty-in this case intellectual-he was supposed to leave and follow his own path.

According to Plato, the goal of the Academy was to educate studentphilosophers who would in the future become rulers. It was based on the premise that the master was responsible for teaching his disciples how to perform socially important functions. Here education is understood as a specific responsibility for the state, and being a master - as the task of preparing the next generation to work for the country and to find the best disciple who will undertake this task. This type of prosocial and civic attitude is also a characteristic of the master-disciple relation which often eludes us when we think only from the individual perspective.

\section{Buddhism}

In the case of Buddhism and its many different variations, the most important issues relating to the master-disciple relationship are connected with the biography of Siddhārtha Gautama, the Shakyamuni, simply known as Buddha. ${ }^{5}$ The origin of

\footnotetext{
${ }^{5}$ The presented biography of Buddha is based on Gabriele Mandel Khân's publication Budda oświecony (2003), as well as a number of essays discussing the different periods of this tradition, collected in Filozofia Wschodu, edited by Beata Szymańska (2001; see especially Kosior 2001a, 2001b; Jakubczak 2001). For a selection of source texts on Buddhism see Kudelska (2002: 217-284).
} 
Buddhism-a philosophical and religious system, a form of spiritual development (Kosior 2001a, 2001b; Jakubczak 2001)—is directly connected with the figure of Buddha Shakyamuni, also called Siddhartha, who lived at the turn of the 6th and 5th centuries B.C. in Northern India.

Buddha was the son of King Śuddhodana and his first wife Maya. Legend says that his life was as marvelous and amazing as was his conception and birth, although from a structuralist perspective these types of stories about the lives of saints can be found in different times and places all around the world. He was born and immediately knew how to walk. He started by walking seven steps, and lotus flowers grew in his footprints. It was the first sign of Buddha's greatness, confirmed by the Brahmins who found birthmarks on his body that demonstrated his extraordinariness, otherness and other supernatural qualities. In the culture of that time this was seen as an equivalent of power, being a prince, ruling over the world, but it could also mean that he would become a monk, an ascetic who would help people free themselves from evil. Buddha's father, the king, did not want his son to live among common people, to see their suffering, misery and unhappiness. He wished for his son to continue his family's rule.

As often happens in legends, it was not possible to escape destiny. During a chariot ride Buddha met four important figures who changed the way he perceived reality. These encounters opened his eyes to old age, since he had met a sick, weak old man, but also- to the suffering caused by a disease-as he had witnessed the grievance of a sick man and had heard his cries of pain. He had also met a funeral procession, which taught him about the existence of death, and a beggar-a hermit and ascetic whose testament had shown him the way forward. After meeting the hermit, Siddhartha asked his father for permission to visit the masters of Samkhya, a Hindu philosophy that teaches liberation (of the spirit from the material body).

This is the beginning of his adventure with masters which reveals new layers of the master-disciple relation, including the idea of an encounter, perhaps as important as the concept of "dialogue." In his journeys, Buddha encounters important and prominent people, however, they are not teachers. They greatly influence his life, but only for a short moment. They are an inspiration. Because of them the hero breaks the existing ways of thinking, and they encourage him to act and change his life. All of these elements are important in different types of road stories or initiation stories (regardless of the times or the cultures they come from, or the genre they belong to). The encounters lead the hero on a new path.

Having left his father's palace, Siddhartha spent the next seven years travelling and seeking wisdom. He met many wise men, and each of them taught him something different, but without providing any answers to the spiritual questions he wished to understand. He learnt how to do physical exercises that helped him achieve nirvana. He trained in interpreting the Vedic scriptures. He practiced concentrating in order to overcome body matter. But everything still seemed worthless to Buddha, since it all remained on the level of rituals, without 
guaranteeing true freedom and the salvation of humanity. He searched for other masters and teachers, but the ascetics seemed equally ineffective as the rulers, and their actions-as ambitious and unrealistic. This proves that transformation never occurs suddenly-it is a process of becoming. Different encounters influence change, but the hero must grow up in order to truly achieve a new sense of life.

What is important in this scenario is the fact that Buddha can be seen as an example of a self-made man, someone who has achieved knowledge, abilities, wisdom and spiritual peace thanks to his own work and decisions. Although transformation is seen as the result of these encounters, it is the hero himself who in fact decides to choose a new life path. There is no guide who could help him, there are only (or is that enough?) inspirations to change. Contrary to the previous examples, here we see a master who seems to emerge out of nowhere. However, we must remember that it is only a description of an ideal type, since the emergence of Buddhism was a historical process, rooted in culture. Indeed, all of the figures Buddha encounters during his journeys are deeply rooted in the Indian traditions and religious beliefs, and are equipped with many meanings.

But let us return to the prince himself. He wished to pursue the middle road, without relying on extreme solutions or radical ideas about life. This helped him to achieve enlightenment and finally become Buddha. Enlightenment was a result of understanding that our consciousness is the sum of unreal, socially-constructed norms, values which influence our behavior, emotions and relationships. Imposed on them are various temptations of the material world, ambitions, the lust for power (including the master's power over his disciple). Indeed all of these are phenomena or facts that are apparent to our self, to our being in the world.

Buddha began to share the knowledge that leads to enlightenment with others, e.g. with merchants who were traveling all over the world and trading goods, which can be foretell the spread of Buddhist thinking. Here we see another important characteristic of the master-disciple relation. The master must present his teachings to those who can in turn pass them to others. The spreading of an idea is crucial in this relationship (as in Christianity are the concepts of evangelization or apostolate), to make sure the idea will continue to live on even after the master is gone. The choice to teach merchants is even more important, since because of their travels they become natural transmitters of ideas.

During his journeys, Buddha gained not only followers and believers, but also disciples, monks who would preach his teachings to others. They accompanied him in his travels, and when they could not-they taught his philosophy to others. The stories about liberation and enlightenment turned out to be convincing enough for the people who heard them that king Bimbisāra offered a gift to Buddha-the Veluvana park, in which he founded his first Vihara, a Buddhist monastery.

Similar to any other social institution, the master-disciple relationship requires material structure, a framework, a piece of land, or simply a setting in time and 
space. We must remember that in most cases a master's school is connected with a specific place. Without the material foundation, the master-disciple relation could not happen or develop. This was apparent in the example of guild mastery, as it is in Buddha's story. It is also an element which we often forget when we talk about defining the master. But the master himself in this specific place can be perceived as a person who explains the world and its mysteries, who introduces novices to a particular way of thinking and living. We may call it the introductory function of the master, just as Witkowski quoted Eliade's notion of the initiating function of a master.

\section{Guru}

The last story concerns a master and a teacher who can be encountered in Hindu society6. The word "guru" translates as "important person" (it is a word from the Sanskrit: "gu" — darkness, "ru" — to save, meaning someone important, honorable, a guide), and a guru is a person who leads others out of darkness, someone enlightening, a teacher, master and spiritual guide. He is highly respected and is an authority figure in his community (and this is an important observation, since a guru can be a domesticated, well-known and familiar person, not necessarily a public one). Gurus were often worshiped as personifications of a deity, but they were also treated not unlike normal teachers (and were thus responsible for the transfer of knowledge more than serving the role of a master). Historically speaking, gurus were leaders in Sikh communities, but the title is also applied to teachers of Vajrayana Buddhism. Additionally, their presence was essential for the spiritual development and enlightenment of individuals, therefore one had to choose a guru who would lead one through the spiritual and mystical paths, helping to avoid mistakes or not to make wrong choices. In this way a guru became a mystagogue, a spiritual leader who would show the way to becoming one with the Divine Being through an inner liberation (moksha).

A guru is an element of traditional Hindu spirituality, and in a broader sense - the entire Indian culture. In India a guru is part of the authoritarian and hierarchical society. Among his believers, a guru is treated with as much respect as a father is in his family, but a young person may choose a guru by himself. However, this is met with ambivalent reactions, since on the one hand we feel fascination, and on the other-a defensive reaction. A master therefore belongs not only to the school system, education, but is also a part of culture, a symbol. And as this symbol-a master belongs to commonly respected people who occupy a high social position. He deserves respect and honor-elements which have already appeared in the previously discussed examples of mastery.

\footnotetext{
${ }^{6}$ For more information on the philosophical and religious traditions of India see Nakamura (2005: 53-175), Szymańska (2001: 11-313).
} 
Initially a guru was a teacher of religion, taking part in every family celebration. This Acharya guru (guru-teacher) taught Hindu religious knowledge, and that which was secular. As a Diksa guru (master of initiation) he had competence to inform people about specific religious practices and prepare them for initiation. He was also responsible for initiating a person to become a monk. Although he was not a priest, the Purohit guru could also fulfill priestly duties. The guru was responsible for the initiation process of his disciple, and because of that was responsible for upholding the social status quo.

A guru would gather his students, for example, to help them learn the yogic practices, so that they could realize their Divine being. The adepts would often pay the guru for his services, and sometimes also pay his family. Therefore, the master was dependent on his disciples. It was not a symmetric relationship. Whereas in most master-disciple relations the asymmetry leans toward the master, in this case it is to the contrary-the master must take care of his livelihood, which depends on his students. We can thus point to another aspect of the mastery relationship that is often forgotten or ignored; but may also play a crucial role even today, in those situations where in the educational system the teacher (no matter whether he is a master or not) is financially supported by the student.

Leszek Wojtczak points to this modern problem when he writes that:

Does a student still need a master? Can a student today, even if he accepts the master, ensure respect in society? Even in the academic community. Is a master still able to find employment for his student? This problem can be stated even more clearly: Under the conditions of market economy, which also regulate academic communities, it is not the master who chooses the student, but the student who chooses the master. It is not the master who promotes the student, who endorses him, who offers him proper conditions for work. It is the student who endorses the master and promotes the master and provides the master with means to receive a promotion. However, it happens very often that a master is a problem for a student, or becomes his rival, for example when applying for the same research grants or awards that are given by the university (1997: 30-31).

In this case it is not only about an asymmetrical relation between a master and a disciple, but about real competition-which in the free market economy system embedded in education, may be the competition between a disciple and a master.

These last remarks have brought us from examples distant in time and space to those which are more contemporary to us (excluding one example), thus creating a kind of narrative temporal and spatial bridge. As will be shown in the next part of 
the article, the various examples discussed above and presented as ideal types can in fact be used also in relation to the present day. Before we move on, it is necessary to organize some of the crucial elements that have appeared in the presented examples in order to juxtapose them with contemporary situations that refer to mastery. Let us use a table summary to present these abstract elements.

Table 1. Traditional/historical paths of mastery

\begin{tabular}{|c|c|c|c|}
\hline Guild & Academy & Buddha & Guru \\
\hline $\begin{array}{l}\text { - education in } \\
\text { a stranger's house; } \\
\text { - education as } \\
\text { collective process, } \\
\text { aimed at the } \\
\text { continuance and } \\
\text { development of } \\
\text { a group; } \\
\text { - education in } \\
\text { a hierarchical } \\
\text { (student- } \\
\text { journeyman-master- } \\
\text { guild) institution } \\
\text { based on laws and } \\
\text { customs; } \\
\text { - guild laws } \\
\text { (charters, contract) } \\
\text { as an impersonal } \\
\text { node connecting } \\
\text { a master and an } \\
\text { apprentice; } \\
\text { - the choice of } \\
\text { a master and } \\
\text { apprentice is } \\
\text { a collective decision } \\
\text { of the guild; } \\
\text { - the master is } \\
\text { responsible for } \\
\text { the livelihood of the } \\
\text { student; in } \\
\text { his home and } \\
\text { workshop. }\end{array}$ & $\begin{array}{l}\text { - dialogue as the } \\
\text { foundation of } \\
\text { teaching; } \\
\text { - leading role of the } \\
\text { scholarch; } \\
\text { - openness to new } \\
\text { ideas and new } \\
\text { people; } \\
\text { - discussions in the } \\
\text { garden, walks etc.; } \\
\text { - after reaching } \\
\text { (intellectual) } \\
\text { puberty the student } \\
\text { must follow his own } \\
\text { way; } \\
\text { - civic and prosocial } \\
\text { education; } \\
\text { - the student must } \\
\text { take responsibility } \\
\text { for the country and } \\
\text { society; } \\
\text { - academy not only } \\
\text { as a school of } \\
\text { philosophy, but } \\
\text { a "forge of staff". }\end{array}$ & $\begin{array}{l}\text { - encounters which } \\
\text { transform the hero's } \\
\text { life, becoming an } \\
\text { inspiration to } \\
\text { change; } \\
\text { - transformation } \\
\text { understood as a long } \\
\text { process of becoming, } \\
\text { growing up, a path; } \\
\text { - Buddha - from the } \\
\text { perspective of an } \\
\text { ideal type - as a self- } \\
\text { made man who only } \\
\text { begins to create } \\
\text { a spiritual and } \\
\text { thought school; } \\
\text { - teaching } \\
\text { knowledge and } \\
\text { promoting your own } \\
\text { ideas; } \\
\text { - the material } \\
\text { furnishing of the } \\
\text { world essential in } \\
\text { the process of } \\
\text { creating and } \\
\text { maintaining master- } \\
\text { disciple relation; } \\
\text { - introductory or } \\
\text { initiatory role of the } \\
\text { master. }\end{array}$ & $\begin{array}{l}\text { - guru understood } \\
\text { not only and not } \\
\text { always as a public } \\
\text { figure, but can } \\
\text { serve his role in } \\
\text { private or semi- } \\
\text { private space; } \\
\text { - oriented towards } \\
\text { spiritual } \\
\text { development, but } \\
\text { also upholding } \\
\text { tradition through } \\
\text { rituals; } \\
\text { - possibility of } \\
\text { choosing a guru by } \\
\text { yourself; } \\
\text { - disciples secure } \\
\text { the livelihood of } \\
\text { the guru and his } \\
\text { family, so that - on } \\
\text { the material level - } \\
\text { there is a reversal } \\
\text { of the master- } \\
\text { disciple relation } \\
\text { and the asymmetry } \\
\text { ascribed in it. }\end{array}$ \\
\hline
\end{tabular}


There are other possible interpretations of the master-disciple relationship present in culture which expand the scope covered in important scholarship devoted to this subject, e.g. in Ewa Marynowicz-Hetka's Mistrz - uczeń. Wyobrażenia czy rzeczywistość, czyli o tworzeniu szkół naukowych (1997) or Lech Witkowski's Historie autorytetu wobec kultury i edukacji (2011). However, if we dig deeper into culture, especially in education, we may discover other clues that can expand the way we perceive the role of the master, or his attributes.

\section{Alternative paths of mastery ${ }^{7}$}

\section{Alchemy}

The first example of an alternative path is alchemy, understood as a magic art ${ }^{8}$ which introduced the motif of initiation into the master-disciple relationship. Initiation-as was already emphasized in previous examples, especially in regard to the craft guild and guru-student relation-is understood as entering into a hidden circle of knowledge in which all of the most important mysteries of human life can be revealed. In this sense it is a pattern that is connected with various rites of passage in different traditions, cultures and times. If philosophy and religion ask questions about the meaning of life and immortality, then alchemy is supposed to provide a practical solution to these questions. It is a craft as well as a practical side of philosophy, a continuation of philosophical action and thinking. In addition to initiation, alchemy brings to life certain rituals connected with passing into a circle of people who have access to the mystery. It also institutionalizes this passage with the use of specialized equipment. Here again the material furnishing of the world (real elements of the symbolic passage) and the craftsmanship (alchemy is not only an abstract philosophy, neither can it be solely considered as magic) turn out to be important components of mastery and the master-disciple relation. Indeed, they are precisely the same elements which played a significant role in the case of being educated in a stranger's home. If we perceive a master only and exclusively in spiritual or intellectual categories, it is necessary to make a correction that will allow us to emphasize this material aspect.

\footnotetext{
${ }^{7}$ The following part of the article consists of a number of loosely connected tropes which could become their own stories about the different roles of the master, his relation with the disciple and his functioning in culture.

${ }^{8}$ And although alchemy has some obvious historical contexts and could therefore function in the first group of ideal types, because of its metaphorical and symbolic understanding in the development of modern variants of mastery I have chosen to present it in this part of the article. An excellent example is the popularity of Paulo Coelho's The Alchemist (1995) and its later use in different types of mastery that are realized today.
} 


\section{E-learning}

As a way of building and maintaining master-disciple relations, equipment is also required in e-learning-that is in teaching with the use of electronic media. In this type of education both the student and the master take on new roles. The former function of a teacher whose role was to transfer knowledge/information must necessarily change. The teacher should abandon the role of a sage and specialist and instead adopt that of a guide who prepares scenarios for classes and works together with students to create new ways of learning which combine different forms of education. The master is no longer an infallible lecturer, but a guide who leads the student along the right path. However, verification does not always happen in real life. The master is no longer the dominating side in this relations - the student's educational needs become more important. The master becomes a mentor, the student-an active constructor of the entire educational process. When compared with previous examples, this introduces a significant change. In the past the disciple could work for the master (guild) or secure a livelihood for him (guru). However, the transmission of knowledge moved in only one direction.

We can assume that with the constant development of new technologies in which the young (pupils, students) are better oriented, this reversal of the master's position will continue to affect the master-disciple relationship. If in the case of the guru the asymmetry was connected with the material (financial) advantage (and obligation) of the student, then here the asymmetry operates on the level of teaching and educating - the essence of the master's position. It is the student who has knowledge how to move through the landscape of new technologies, and knows it better than the teacher (is he still a master, then?), even though it is the latter who is still-at least formally-doing the teaching (the issue of upbringing is difficult to settle in this case). In this context it is helpful to return to categories introduced by Margaret Mead (1978), since it is apparent that mastery as something characteristic for postfigurative cultures in which the elders pass on knowledge to the young, crosses into a prefigurative culture, in which the older generation cannot keep up with the rapidly changing world, and it is up to the young to take over the role of guides and to chart new directions. The rapid development of new technologies and new media is a perfect exemplification of this process.

Since at least the time of Marshall McLuhlan (2001) this type of relation has undergone significant reformulation and revaluing from the perspective of media studies, especially when considering the role of media in the transfer of knowledge. The student engages in a dialogue with the master, but a new element is added to this dialogue-a computer with internet access. As a result, the master-disciple relationship becomes more than personal (perhaps even impersonal; or mediated through a mediatized, virtual personality). If we accept Bruno Latour's Actor- 
Network Theory (2010), we can argue that mastery perceived from the perspective of e-learning is at the same time a synergy between human (master, student) and non-human factors (computers, smartphones, the internet etc.).

\section{Emotional mastery}

Referring to Daniel Goleman's concept, we can also talk about emotional mastery. ${ }^{9}$ Goleman's book was published in the same period that Francis Fukuyama famously declared that we are witnesses to "the end of history" (1996). World economies were advancing thanks to capitalism and neoliberal democracies, built on such values as individual autonomy, competition, (hyper)individualism. At the same time interpersonal and intergenerational solidarity was disappearing, replaced with fear and anxiety about the future (Bauman 2006, 2007; Beck 2012). Some of the effects of this transformation had to do with emotional incongruity, a lack of understanding of human relations, depression and desperation, frequently ending in aggression. That is why Goleman's idea was (initially) greeted with enthusiasm, firstly - in order to measure and evaluate emotional intelligence, and secondly - in an attempt to shape and strengthen it. For this reason it is necessary to emphasize the importance and strong influence of masters on the emotional states of their disciples. Today's master must know the reality of social life, as well as both the intellectual and psychological state of his students. The master can be seen as a sort of therapist, a psychologist who teaches lessons on self-knowledge and selfprogress (similar to a coach, a trainer, a tutor). It is especially important in our multicultural times when we need to engage in dialogue with Others and Strangers. It is also connected with the new tasks required from schools, which are no longer supported by increasingly dysfunctional families. For this reason schools and teachers alike have to be prepared for these new tasks, greatly surpassing both the school's structure and organization, and the teachers' competences and education. Naturally, these are possible new approaches to, or new contexts for understanding contemporary mastery, which has undergone a process of redefinition (similar to the example of e-learning) when compared to its more traditional form. Even if we are not able to fully realize, name, define or conceptualize them, nevertheless these kinds of imaginary (social) experiments can help us to create structures and (social) institutions that will aid our development, or the transfer of knowledge that will be adequate to the needs, while also helping students to engage with the new world.

\footnotetext{
${ }^{9}$ Although Daniel Goleman's work is not necessarily considered as a proper academic publication, it nonetheless did expand the vocabulary of the social sciences by characterizing a particular type of intelligence, or rather a certain type of sensitivity to the needs of the other person, paying attention and being empathetic (Goleman 1997).
} 


\section{Tutoring}

Another example of new tendencies we can include-or rather, which include themselves-in the master-disciple relation are various new figures such as those of a trainer, a coach, a mentor, a leader or-what will be discussed as the primary example of this tendency-a tutor. ${ }^{10}$ The master-disciple relationship is often treated as a base for tutoring, understood as an individualized, direct and elitist method of teaching. Its beginnings are connected with the English universities of the Middle Ages, although, as some sources claim, this method was initially developed outside of the university, and the first "tutors" were graduates hired by aristocratic families (here we can see some similarities with the Hindu guru, yet without the evident spiritual component of teaching). Tutoring proved to be such a success that in the $19^{\text {th }}$ century it was introduced as a common method of teaching at Oxford University. Regulations were set up, with the main rule being the teacher-pupil meetings considered as the general form of education, completed with lectures and seminars. During the term a student (indeed it is an asymmetric relation, oriented at the student and not at the master) takes part in eight to twelve tutorials, which are simply meetings with the teacher. During the tutorials the student presents an essay he has worked on, and that paper forms the basis of an ensuing discussion. The essay collects the student's thoughts on a topic chosen by the teacher. The aim of these tutorials is to prepare the student for the exam, and for the teacher to verify the student's knowledge on particular subjects (which the student learns by himself, e.g. by searching for relevant sources). In the end the student has the possibility to broaden his horizons, learn new abilities and master new competences.

Today tutorials are a popular method also in Poland. There are several institutions with have a long tradition of educating children, adolescents and students with the application of this method. An interesting Polish example of tutoring is the academic society Collegium Invisibile (CI) which was founded to help particularly gifted students as well as to prevent-as is stated on their website - "the destructive influences of the masses on higher education." 11 The society consists of professors and students who work together within the master-disciple paradigm, and is inspired by the experience of prestigious British universities. The idea behind Collegium Invisible also references the $18^{\text {th }}$ century Collegium Nobilium - that is why one of its aims is to help advance responsible civic attitudes. Students who are accepted into the tutoring program of the Collegium receive

\footnotetext{
${ }^{10} \mathrm{I}$ focus on tutoring since it is a method that is closely aligned with academic practice. However, both mentoring and coaching could be also mentioned, growing from the identical course-the cooperation between a master and a pupil. There are many publications dedicated to them, in which tutoring is connected with education (at every level), mentoring with business, and coaching with work on resources and individual psyche.

${ }^{11} \mathrm{http}: / /$ ci.edu.pl/ [accessed: 20.09.2018].
} 
a chance to work with excellent Polish professors who are recognized as authority figures in their respective fields (but not only, since students may also choose guardians from outside of their field). The tutorials (although not as intense as the ones at the University of Oxford) enable students to follow an individual academic path. Each year more than a dozen talented students join the organization, also as part of a program dedicated for high school pupils who are the beneficiaries of the National Children's Fund. ${ }^{12}$ "The First Tutor program" connects the Collegium students with ambitious high school pupils (who chose both the subject and material). The CI aspires for its graduates to play a significant and active role in the academic and social life in Poland.

Another academic example is the "Artes Liberales" Collegium founded by professor Jerzy Axer (also the creator of the interdisciplinary individual studies in the humanities program). One of the ideas behind the creation of "Artes Liberales" was the cooperation of a student with a master who introduces him to the academic world and facilitates his intellectual development. Their website states that: "Collegium Artes Liberales is a university which up until now was only a dream. It is a collaboration between professors and students who learn from each other. It is an experiment in which no one remains passive, but every member constantly searches for and works on his or her spiritual and intellectual self-improvement."13 Each student has a chance to take part in an individual studies program coordinated by a tutor which corresponds to their individual preferences and passions. The "Artes Liberales" students are given the possibility of choosing disciplines and courses that were available in the eight cooperating universities (University of Warsaw, Jagiellonian University, John Paul II Catholic University in Lublin, Nicolaus Copernicus University in Toruń, Adam Mickiewicz University in Poznań, University of Wrocław, Marie Curie-Skłodowska University, and University of Silesia). ${ }^{14}$

Tutoring is also practiced at the school and preschool levels, e.g. by the "Sternik" Association. It considers tutoring in the context of personalized education which aims for the comprehensive development of a young person. From this perspective a tutor is seen as a family guardian, someone who helps the family prepare an individual development plan for the child. The tutor is responsible for getting to know the child and in helping him to advance his skills. The parents regularly meet with the guardian (most often three times a year) to discuss the educational progress of their child. Therefore the master's (masters') guardianship is not limited only to the pupils themselves, but it also covers their closest surroundings, parents or legal guardians.

\footnotetext{
${ }^{12}$ http://fundusz.org/ [accessed: 20.09.2018].

${ }^{13} \mathrm{http}: / /$ www.aal.edu.pl/node/385 [accessed: 20.09.2018].

${ }^{14} 2017$ was the last year of enrollment to the MPISD AAL program. BA and MA studies were closed in the year 2011/2012.
} 
Similarly as in the case of the previous four examples, we can organize the most important elements of the ideal type of each of the alternative paths of mastery so that we can point to both similarities and differences between these models.

Table 2. Alternative paths of mastery

\begin{tabular}{|l|l|l|l|}
\hline \multicolumn{1}{|c|}{ Alchemy } & \multicolumn{1}{|c|}{ E-learning } & Emotional mastery & \multicolumn{1}{c|}{ Tutoring } \\
\hline - initiation of the & - advances in new & - the addition of the & - new figures of the \\
student into the & technologies (IT), & category of & master: tutor, coach, \\
circles of secret & especially & to the previously & trainer, mentor, \\
knowledge, & communication & leader; \\
hidden, but & (ICT); & - tutoring as \\
relating to the & - asymmetry in the & intelligence, & a method of \\
most important & master-disciple & wisdom or & individualized elitist \\
problems & relation - the & spirituality; & education; \\
connected with & domination of & - focus on the & - effectiveness of this \\
human life; & students as a result & disciple's emotions & model of educating; \\
- rite of passage; & of the move from & and emotionality, & - self-improvement \\
- alchemy & postfigurative to & which requires new & connected with \\
understood as & prefigurative & skills from the & individual work; \\
a type of craft; & culture; & master; & - a way to overcome \\
- the real & - the role of media & - the master as & the weaknesses of \\
(practical) and & and mediality in the & therapist and & mass education; \\
symbolic role of & transfer of & psychologist; & - academic and civic \\
the material & knowledge; & - dialogue with & development; \\
furnishing of the & - soft- and hardware & Others in the & - other actors \\
world in the & as a crucial non- & contemporary & engaging in the \\
development of & human component & globalized and & master(tutor)- \\
the master- & shaping the master- & multicultural world. & disciple relation, e.g. \\
disciple relation. & disciple relation. & & the student's parents \\
& & & or other family \\
& members. \\
\hline
\end{tabular}

\section{Conclusion}

Ewa Marynowicz-Hetka is right when she asks about the significance of discussing the role of masters today, pointing to the importance of the relationship:

The time of social transformations makes more visible the social context of educational processes, the shape of this relation in the academic world, understood as a social institution and as a realization of its social function, which is on the one hand to stimulate research and continue discovering new spaces, and on the other hand to preserve tradition and cultural heritage (1997: 11). 
The figure of the master interweaves that which is contemporary and prodevelopment with that which is traditional and aimed at protecting our heritage. The paradox pointed by Marynowicz-Hetka-the combination of seemingly exclusive elements-is indeed the true essence of mastery. It should therefore be no surprise how many of these threads were discussed in this article. Some of them exclude, others complement each other; some are constantly returning leitmotifs, others are deeply embedded in a given tradition and connected to a specific time in history. All of these different contexts centered around the master's functioning both in the past and in the present, especially in terms of modern educational challenges, can be presented in the following form: ${ }^{15}$

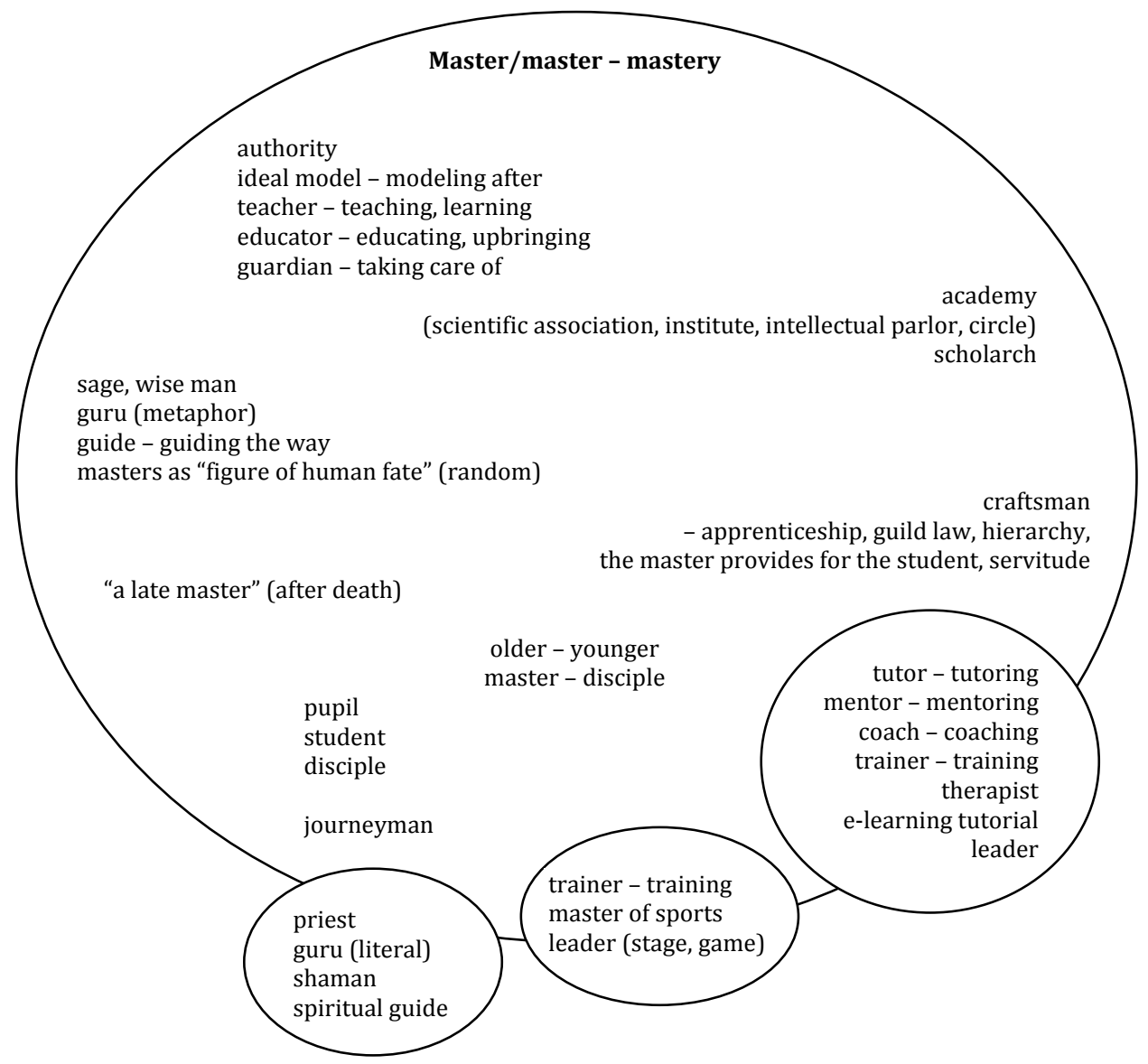

Diagram 1. Master/master - mastery

\footnotetext{
${ }^{15}$ The diagram was constructed by Adam F. Kola for a panel discussion about masters (called Mistrzowie. Premilinaria, organized by Marcin Kafar and Adam F. Kola as part of the Humanistic Forum at the Institute of Educational Research at the University in Łódź and the Collective Memory in Post-Communist Europe Research Group at the Nicolas Copernicus University in Torun, which took place on December 12, 2015 in Torun. The original diagram was updated and expanded for the needs of this article-A.M.K.
} 
This diagram is not free from controversies. For example, the presence of such figures as a coach or trainer in the field of mastery can be considered questionable. The main part of the diagram consists of terms which directly-also in this article-relate to mastery and the master-disciple relationship. The left column directly refers to the master in the upper part, and to the pupil in the lower part, in both cases focusing on their different roles and functions. The right column consist of two groups of terms: the upper refers to the academy, the second to the craft guild. Three smaller circles which align with parts of the main circle but are not limited to it, include terms which because of their outside contexts do not refer directly to mastery. Looking from the left: the first refers to the religious sphere, the second to sports, and the third to modern techniques of personal development and education. In this sense they are not free from controversy, but as both the historical and contemporary examples discussed in this article have proved thus far, mastery is not a homogenous phenomenon and does not have clearly defined boundaries. It is dynamic, changes through time and in different cultures, is always rooted in society, strongly linked with the political or even economic context. As a result, the semantic field of the term "master" or "mastery" is indeed very wide, as the presented diagram attempts to show (and I am fully aware of the fact that we could list many other possibilities).

However, another issue is important in the educational context. The continuous updating and re-contextualizing of these categories and tropes of how to understand mastery may lead to new ways of utilizing this figure in didactic and educational processes. The master is not only and exclusively connected with some long-forgotten past ("the good old days"), nor does it have to be a conservative category. On the contrary, the figure of the master has the potential to introduce and expand educational and social innovations. The master does not have to be a frozen category, but a figure full of life. Broadening the horizon of expectations -mentioned in the first part of this article-is indeed the most important challenge standing before anyone wishing to update the ideas of a master and mastery in today's educational context.

Finally, we can quote the words of Jacek Piekarski, who in his work dedicated to masters and disciples rightly argues that "It is difficult to judge if the fact that we are still talking about the master-disciple relationship today is a result of an experienced deficit of meaning related to that relation, or is it the result of our difficulties in reading it" (1997: 16). I believe in the second answer, which also gave me the impulse to write this essay. Perhaps after analyzing the various themes and narrative strands presented on these pages the difficulties will seem far less serious, which may help us to employ the contemporary role and position of a master with much more success. "To understand the rest of the specific terms would perhaps require the creative participation of an embodied master" (Witkowski 2007: 277). 


\section{References}

Bauman Z. (2006) Płynna nowoczesność [Liquid Modernity], transl. by T. Kunz, Kraków, Wydawnictwo Literackie.

Bauman Z. (2007) Płynne czasy: życie w epoce niepewności [Liquid Times: Living in an Age of Uncertainty], transl. by M. Żakowski, Warszawa, Wydawnictwo Sic!

Beck U. (2012) Społeczeństwo światowego ryzyka: w poszukiwaniu utraconego bezpieczeństwa [Weltrisikogesellschaft: Auf der Suche nach der verlorenen Sicherheit], transl. by B. Baran, Warszawa, Wydawnictwo Naukowe Scholar.

Chałasiński J. (1928) Wychowanie w domu obcym jako instytucja społeczna: studjum z socjologii wychowania, Poznań, Fiszer i Majewski: PIS.

Coelho P. (1995) Alchemik [O Alquimista], transl. by B. Stępień, A. Kowalski, Warszawa, Drzewo Babel.

Fukuyama F. (1996) Koniec historii [The End of History and the Last Man], transl. by T. Bieroń, M. Wichrowski, Poznań, Zysk i S-ka.

Goćkowski J., Siemanowski A. (Eds.) (1981) Szkoły w nauce: praca zbiorowa, Wrocław, Zakład Narodowy im. Ossolińskich.

Goleman D. (1997) Inteligencja emocjonalna [Emotional Intelligence: Why It Can Matter More Than IQ], transl. by A. Jankowski, Poznań, Wydawnictwo Media Rodzina.

Havelock E. A. (2007) Przedmowa do Platona, transl. by P. Majewski, Warszawa, Wydawnictwo Uniwersytetu Warszawskiego.

Husserl E. (1975) Idee czystej fenomenologii i fenomenologicznej filozofii, transl. by D. Gierulanka, R. Ingarden, Warszawa, Państwowe Wydawnictwo Naukowe.

Husserl E. (1982) Medytacje kartezjańskie, transl. by A. Wajs, Warszawa, Państwowe Wydawnictwo Naukowe.

Jakubczak K. (2001) Filozoficzne szkoły buddyzmu mahajany - madhjamaka i jogaczara in: Filozofia Wschodu, B. Szymańska (Ed.), Kraków, Wydawnictwo Uniwersytetu Jagiellońskiego: 207-244.

Khân G. M. (2003) Budda oświecony [Buddha L'illuminato], transl. by H. Borkowska, Warszawa, Muza.

Kosior K. (2001a) Buddyzm pierwotny in: Filozofia Wschodu, B. Szymańska (Ed.), Kraków, Wydawnictwo Uniwersytetu Jagiellońskiego: 181-196. 
Kosior K. (2001b) Wczesne szkoły buddyjskie. Abhiddharma in: Filozofia Wschodu, B. Szymańska (Ed.), Kraków, Wydawnictwo Uniwersytetu Jagiellońskiego: 197-206.

Kot S. (1996) Historia wychowania, vol. 1, Od starożytnej Grecji do połowy wieku XVIII, Warszawa, Wydawnictwo Akademickie „Żak”.

Latour B. (2010) Splatają na nowo to, co społeczne: wprowadzenie do teorii aktora-sieci [Reassembling the Social. An Introduction to actor-Network Theory], transl. by A. Derra, K. Abriszewski, Kraków, Universitas.

Marynowicz-Hetka E. (Ed.) (1997) Mistrz - uczeń. Wyobrażenia czy rzeczywistość, czyli o tworzeniu szkół naukowych, Łódź, Łódzkie Towarzystwo Naukowe.

McLuhan M. (2001) Wybór tekstów, transl. by E. Różalska, J. M. Stokłosa, Poznań, Zysk i S-ka.

Mead M. (1978) Kultura i tożsamość: studium dystansu międzypokoleniowego [Culture and Commitment: A Study of the Generation Gap], transl. by J. Hołówka, Warszawa, Państwowe Wydawnictwo Naukowe.

Nakamura H. (2005) Systemy myślenia ludów Wschodu. Indie, Chiny, Tybet, Japonia [Ways of Thinking of Eastern People: India-China-Tibet-Japan], P. P. Wiener (Eds.), transl. by M. Kanert, W. Szkudlarczyk-Brkić, Kraków: Wydawnictwo Uniwersytetu Jagiellońskiego.

Plato (2002) Fedon [Phaedo], transl. by W. Witwicki, Kęty, Wydawnictwo Antyk.

Reale G. (2001) Historia filozofii starożytnej [A History of Ancient Philosophy II. Plato and Aristotle], vol. 2, Platon i Arystoteles, transl. by E. I. Zieliński, Lublin, Redakcja Wydawnictw Katolickiego Uniwersytetu Lubelskiego.

Rybicki P., Goćkowski J. (Eds.) (1980) Autorytet w nauce: praca zbiorowa, Wrocław, Zakład Narodowy im. Ossolińskich.

Saussy H. (2006) Exquisite Cadavers Stitched from Fresh Nightmares: Of Memes, Hives, and Selfish Genes in: Comparative Literature in an Age of Globalization, H. Saussy (Ed.), Baltimore, The John Hopkins University Press: 3-24.

Stróżewski W. (2007) Promieniowanie mistrza, „W drodze”, 2 (402), http://www. wdrodze.pl/miesiecznik/index.php?mod=archiwumtekst\&id=12327\#.W6k36fZpzIU [accessed: 20.09.2018].

Szymańska B. (Ed.) (2001) Filozofia Wschodu, Kraków, Wydawnictwo Uniwersytetu Jagiellońskiego. 
Tatarkiewicz W. (1998) Historia filozofii, vol. 1, Filozofia starożytna i średniowieczna, Warszawa, Wydawnictwo Naukowe PWN.

Weber M. (2011) Racjonalność, władza, odczarowanie, transl. by M. Holona, A. Kopacki, Poznań, Wydawnictwo Poznańskie.

Witkowski L. (2007/2016) Między pedagogikq, filozofiq i kulturq. Studia, eseje, szkice, Warszawa, Instytut Badań Edukacyjnych.

Witkowski L. (2011) Historie autorytetu wobec kultury i edukacji, Kraków, Oficyna Wydawnicza Impuls.

Znaniecki F. (1928) Socjologja wychowania, vol. 1, Wychowujące społeczeństwo, Warszawa, Skł. gł. Książnica-Atlas.

Znaniecki F. (1930) Socjologja wychowania, vol. 2, Urabianie osoby wychowanka, Warszawa-Lwów, Nakł. Naukowego Towarzystwa Pedagogicznego, skł. gł. KsiążnicaAtlas.

Znaniecki F. (1984) Społeczne role uczonych, transl. by J. Szacki, Warszawa, Państwowe Wydawnictwo Naukowe.

\section{Online sources}

http://ci.edu.pl/ [accessed: 20.09.2018].

http://fundusz.org/ [accessed: 20.09.2018].

http://www.aal.edu.pl/ [accessed: 20.09.2018]. 